\section{I $\mathbf{B} \mathbf{A}$ Institute of \\ YK Business Administration \\ तर Karachi \\ Leadership and Ideas for Tomorrow}

Article 4

Volume 7 Issue 1 January-June 2012

$1-1-2012$

\title{
G-20 summit and debt crisis of Europe
}

\author{
Badar Alam Iqbal \\ Monarch University, Switzerland
}

Follow this and additional works at: https://ir.iba.edu.pk/businessreview

Part of the Business Commons, Finance Commons, and the International Economics Commons

(c) (i)

This work is licensed under a Creative Commons Attribution 4.0 International License.

\section{Recommended Citation}

Iqbal, B. A. (2012). G-20 summit and debt crisis of Europe. Business Review, 7(1), 43-53. Retrieved from https://doi.org/10.54784/1990-6587.1300

This article is brought to you by iRepository for open access under the Creative Commons Attribution 4.0 License and is available at https://ir.iba.edu.pk/businessreview/vol7/iss1/4. For more information, please contact irepository@iba.edu.pk. 


\title{
ARTICLE
}

\section{G-20 Summit and Debt Crisis of Europe}

\author{
Badar Alam Iqbal \\ Monarch University, Switzerland
}

\begin{abstract}
Europe is under debt threat, facing the biggest crisis of uncertainty. If Euro fails, Europe fails. Since the Second World War, this is the hardest hour for Europe. One of the biggest limitations of global integration of EU is that small and weak countries could not fall in line with strong economies. This crisis is the example in this regard. The recent summit at Cannes has failed in giving concrete solution to the debt crisis especially in case of Greece, Italy, Portugal, Ireland and Spain. The crisis in Greece and Italy cost the resignations of two popular Prime Ministers. The debt crisis is pushing the EU in general and Greece, Portugal, Spain, Ireland and Italy in particular in recession. Accordingly, the growth forecast is reduced to 0.5 per cent in 2012 from 1.8 per cent. EU agrees on new treaty. The present paper deals with the major issues, with which the Euro zone is confronting with.
\end{abstract}

Key words: Euro-zone, unemployment, commodity prices, double-dip recession, fiscal sustainability, monetary union, hype-inflation, Second World War, Lisbon treaty

\section{Introduction}

The global economy that has witnessed a recovery from the world crisis has again entered into a new phase of economic crisis and, as a result, economic growth in advanced economies has come to standstill and many economies have started witnessing second recession especially in Europe. The situation is very shocking and precarious as global unemployment stood at 200 million world over. These trends and situation have compelled the global leaders to come together at Cannes to find some amicable solution to the most strategic issues that Europe in particular and the world in general is facing in present century.

German Chancellor has rightly observed that the present turmoil in Europe was sparked by the Euro zone debt crisis, being the continent's hardest hour since Second World War and further opined that if the Euro fails, Europe fails. Other Europe leaders called the current debt crisis as an existential moment and predicted the death of a federal Europe if the crisis is not resolved and therefore, the G-20 leaders have to play a strategic role to save Europe.

The G-20 summit at Cannes cannot be considered successful. The persisting unemployment levels in developed countries along with high degree of tension in financial markets have resulted into sovereign risks in Europe. These trends have resulted in slowing down of growth in the emerging markets whereas commodity price swings have further resulted in growth and imbalances at risks.

The existing grim overview of the world situation presented by the global leaders in the concluding document is being considered as a disappointment. Economies that are looking relatively inflexible may emerge as more flexible. The fact is the real extent of 
concessions taken from emerging economies in general and China in particular is very easy to come out with fine words but extremely difficult to transform into reality or action.

Progress attained on social issues particularly through Business Summit and the Labour Summit, which were held together, shows that no concrete commitments were extended by developing nations to counteract social dumping. The European nations are blaming developing economies and their social dumping for increased delocalization and outsourcing with a consequent rise in unemployment in the developed world.

\section{Greatest fear}

The International Labour Organization (ILO) has issued a serious warning that a job crisis created by the slowing down and possible second recession (double dip recession) in the world economy may result in social unrest in both the developed and poor economies of the world. With darkening prospects for employment, policy makers are running out of time to avoid the most dangerous 'double dip recession' that could happen in labour markets.

According to an ILO report, 'Only 50 per cent of the 80 million jobs required to return employment to its pre-crisis levels are likely to be created in the coming two years, and that the stalling of the world recovery has already resulted into joblessness'. This is just adding fuel to fire. In a new social unrest index, there is an increasing unhappiness over the lack of employment and anger over perceptions that the burden of the persisting crisis is not being shared fairly by the concerned economies. The most noteworthy and alarming trend is that more than 45 nations out of 118 economies covered by the report are at the risk of increasing social unrest, along with signs of mounting tensions in the Europe, the Middle East and marginally in the Asian region.

The ILO data indicated that unemployment in European Union that consists of 17 nations has gone up 10.5 per cent, the largest ever during the last 15 years. The biggest sufferers are the youth whose unemployment has touched 29 per cent in Italy, 43 per cent in Greece and 48 per cent in Spain. The next few months of 2011 and 2012 will be of paramount significance with regards to avoiding a sharp decrease in employment and further may result in an aggravation of social unrest.

Another study carried out by Organization for Economic Cooperation and Development (OCED) has observed a marked slowdown in economic operations in the developed world especially in developed West during the last six months. The organization has suggested that G-20 leaders should be bold enough at the summit to avoid a repetition of the collapse that followed the Lehman Brothers bankruptcy in September 2008.

\section{Fear of protectionism}

The Europe debt crisis may lead to revival of protectionism. The fulcrum has shifted, when it comes to economic growth, the coming up emerging economies namely-Brazil, Russia, India, China and South Africa include the factors of recovery, stability and growth. G-20 as a group had played a key role in ensuring that large scale job losses did not take place across the globe. G-20 is an inclusive and representative platform, of which the newly emerging nations have become the integral part of summit at Cannes.

There could be a possibility of revival of protectionism at a time when the sovereign debt crisis engulf some of the fragile European economies. It is an undisputed fact that in difficult times, the tendencies to have protective measures, is something the G-20 Group must reassure the world that it will not be happen. What is immediately needed is to complete 
and finalize the ongoing WTO negations and also correct historical imbalances to make the New Economic Order more equitable and more accessible.

The protectionism could be avoided if the required reforms are made out in case of Brettonwood institutions namely the International Monetary Fund (IMF) and International bank for Reconstruction and Development (IBRD). The new multilateral trading system must reflect contemporary world realities.

Global leaders showed impatience and irritation in respect to Europe's inability to defeat its two year financial crisis as these leaders urged upon a swift resolution for the sake of the world economy.

With Greece's debt-ridden economy at a risk of collapse, European policy makers are pushed to flesh out and enact a week old rescue plan that has already witnessed signs of unraveling. Europe is grappling with lack of confidence in markets and hence, it has become imperative for global leaders to act upon boldly.

Greece is in focal point for policy makers and investors. The present referendum which the Prime Minister has put forth for bailing out his country, would have impact on the future Membership of Greece to EU (after the resignation of the Prime Minister, the issue of referendum is lost). Greece, whose two year bond yield topped 100 per cent, faces the 'real danger' of a disorderly default, risking a run on banks at home and abroad.

Greece's place within EU could not be put in doubt. This attainment by the Greek people could not be based on a referendum. Greece has to make Euro 8 billion in bond repayments in December 2011, the first of which is due on December 19, 2011. The EU portion of the Euro 8 billion trance of aid has been signed off by Euro-zone finance ministers. The EU bailout plan, which includes debt relief for Greece, a recapitalization of European banks and a leveraging of the block's rescue fund, the European Financial Stability Facility (EFSF) is meant to stem the two years old crisis.

\section{Outcome of the Summit}

Global leaders have failed to agree on how to strengthen the International Monetary Fund (IMF) to reverse the European debt crisis. These leaders struggled to reach concrete resolutions and the summit was completely overshadowed by Greece's political turmoil and worries about Italy. No nation outside EU had committed any money to the region's bailout fund.

Emerging economies namely-Brazil, Russia, India, China and South Africa (BRICS) have refused to give any concrete commitments and hence, where would the Euro-zone find money to boost its bail out fund for debt-ridden nations namely- Greece, Italy, Portugal, Ireland and Spain?

The President of European Central Bank opined, with the recession looming, the Euro zone may find some support from BRICS countries. European policy makers are looking beyond their borders to more than double the spending strength of their Euro 440 billion or $\$ 608$ billion rescue fund.

The only concrete measure to emerge from the summit is that debt-ridden Italy has agreed to position itself under trimestrial supervision of the IMF. Other than that, weary leaders admitted that the results of the meeting that brought together leaders of the globe's biggest countries are meager when compared to earlier encounters marked by real sense of progress at international cooperation. 


\section{Worthy role}

Emerging new economic powers namely-China, Brazil, and South Africa would be deciding whether helping Euro-Zone is a worthy investment and accordingly, these economies are quick enough to show that they would channel out their money through IMF.The European Union would now accelerate work on the guidelines of the EFSF and then call on IMF members to contribute to EFSF.

The BRICS nations will contribute to Europe in line with their current voting rights at IMF. The IMF may receive a broader fillip after the UK backed an increase in the fund's $\$ 391$ billion war chest to give bigger crisis fighting role. There is an urge upon IMF to expedite a new liquidity line for countries that have strong and sound policies and fundamentals facing outside shocks. When the globe is in crisis, it is high time that all should consider boosting the resources of IMF. In the face of uncertainty over events in Greece, ways and means should be found to manage the situation so that a package can be put in place as quickly as possible.

\section{Role of IMF}

Emerging nations are supporting the IMF role in restoring stability in Europe. But at the same time IMF must also keep in mind the liquidity need of developing nations who are not at the center of the crisis, but may nevertheless be adversely affected as innocent bystanders. Since multilateral development banks are playing an important role in mobilizing and deploying world savings, the global leaders should raise their respective levels of ambition for these institutions especially IMF so that these agencies could play a transformational role.

The task of restoring fiscal sustainability over the medium-term calls for very different policy and programs prescriptions. World community must focus on structural reforms in all G-20 nations to enhance efficiency and competitiveness over the medium term.

\section{A Case of Greece}

The feeling of confidence, which is the need of the hour, created by the agreement made out of Greece to EU (after the resignation of the Prime Minister, the issue of referendum is lost). Greece, whose two year bond yield topped 100 per cent, faces the 'real danger' of a disorderly default, risking a run on banks at home and abroad.

Greece's place within EU could not be put in doubt. This attainment by the Greek people could not be based on a referendum. Greece has to make Euro 8 billion in bond repayments in December 2011, the first of which is due on December 19, 2011. The EU portion of the Euro 8 billion trance of aid has been signed off by Euro-zone finance Ministers. The EU bailout plan, which includes debt relief for Greece, a recapitalization of European banks and a leveraging of the block's rescue fund, the European Financial Stability Facility (EFSF) is meant to stem the two years old crisis.

\section{Latest Development in Greece}

The debt crisis in Greece has resulted into the resignation of the Prime Minister on one hand and on the other hand the appointment of senior practical banker as a Prime Minister of Greece so that he could keep the debt-strapped country out of bankruptcy and firmly remain part of 17 nations EU. The most difficult task before the Prime Minister is to secure and implement the decisions of a Euro 130 billion or US \$ 177 billion European debt deal 
agreed upon during G-20 Summit in October 2011. That deal is Greece's second massive bailout, after the first Euro 110 billion or US \$ 150 billion rescue package was deemed not enough to keep Greece from bankruptcy.

\section{A Case of Italy}

After Greece the second most debt ridden country in EU is Italy which has caused uncertainty in the entire Euro-zone. The Italian borrowing costs soared way above sustainable levels and the immediate task is to restore the credit worthiness of Italy. The formidable challenge before the nation is how to coup with painful austerity measures. What is needed is implementation of financial stability law wherein economic reforms are promised to carry out by the Italian Government.

Italian Government has sold out Euro 5 billion or US \$ 6.8 billion Treasury Bills of one year maturity at the biggest yield in 14 years after contagion from the debt ridden economy which has resulted into highest borrowing cost. The Rome based Treasury sold at 5 Euro billion of 1 year to yield 6.087 per cent, the biggest since September 1997 and up from 3.57 per cent at the last auction of similar maturity securities. Demand was 1.99 times the amount on offer, compared with 1.88 times in October 2011.

The most alarming impact of increase in borrowing cost is that LCH Clearnet SA demanded more collateral on nation's debt. The yield on Italy's 10 year bond yield crossed the 7 per cent level that led Greece, Portugal and Ireland to seek bailout. The 10 year yield declined marginally at 6.933 after the auction in Rome, pushing the difference with German bonds to 5.17 percentage points.

A prolonged time or 10 years bond yields in excess of 7 per cent alongside a faltering economy is a dangerous mix, and Italy's debt dynamics could result into an unsustainable and ultimately insolvent position. Italy has cash reserves amounting to Euro 35 billion and hence could prove to be a needed cushion that may allow the Treasury to skip auctions later in the coming year 2012 .

The most disturbing trend is that Italy can not afford to stay out of the global financial market for long period of time. Italy's debt stood at 1.9 trillion Euros and the same is bigger than that of Greece, Spain, Portugal and Ireland combined debt. Italy faces nearly 200 billion Euros in bond maturities in 2012 and another 108 billion Euros of bills.

The first bond redemption comes on February 1, 2012, when Italy must pay back 26 billion Euros for debt sold 10 years ago. The possibility is that major risk for Italy is not necessary escalating bond yields, but rather a "buyer strike at a debt auction".

\section{France's top rating at risk}

An increase in French Government borrowing costs, slowing growth and the Eurozone debt crisis threatens the country's top credit rating. France is fighting desperately to retain its 'triple A' credit status, and accordingly, has slashed spending and tightened up on tax revenues, in an effort to sustain and stabilize its strained public finance. But the markets are not convinced.

The difference in yield between France and Germany 10 year Government bonds breached 200 basis points, a euro-era record amid increased economic and financial market uncertainty in the region. Elevated borrowing costs persisting for an extended period would amplify the fiscal challenges the French Government faces amid a deteriorating growth outlook, with negative credit implications. 
Even though the spread between France and Germany borrowing costs has since narrowed slightly, France still pays nearly twice as much as Germany for long term funding. With the Government's forecast for real (GDP) growth of a mere 1.0 per cent in 2012, a higher interest burden would make achieving targeted fiscal deficit reduction more difficult and may add fuel to fire.

\section{Role of ECB}

The policy makers of European Central Bank (ECB) are of the view that the bank can not do much more to stem Europe's sovereign debt crisis and it is reluctant to ramp up bond purchases to downgrade Italy's borrowing costs on one hand and on the other hand to maintain credit worthiness. There is an enormous pressure on ECB to step into the breach to hold EU's monetary union intact.

The ECB till date has so far purchased 183 billion Euros or US \$ 249 billion worth of distressed nations' bonds and the main aim of this act is to ensure its interest rates are transmitted on financial markets which are in doldrums. In order to prevent the purchases from fueling inflation, the ECB sterilizes them by draining the same amount of money these create from the banking system. The ECB could maintain its bond buying as long as it could continue to remove the same amount of money from the system. The bigger the portfolio, the more difficult it becomes to manage, and interventions could only have temporary and very limited effect. The ECB could sterilize up to 300 billion Euros which is a natural limit.

The European Central bank stepped an accelerating sell-off of Euro Zone Government bonds. European shares and the bonds of weaker Euro-zone nations recovered initially on the move on the day Italian new Prime Minister designated.

\section{Violation of Euros Treaty}

Purchasing of bond, keeping in mind the aim of bailing out a country's government is a monetary phenomenon and is prohibited under the Euros founding treaty. Germany's experience of hyper inflation after First World War is a reason why such action should never be contemplated again. It is clearly beyond the mandate of Central Bank of Europe, ECB is not 'lender of last resort' and it is not advisable for the European Governments to ask ECB to become the lender of last resort. Such act will lead to a situation wherein the ECB would lose its independence.

\section{Shadow of China}

The shadow of China also looms over the Summit. The decision by the Euro-area leaders to seek outside funding for the European Financial Stability Facility (EFSF), essentially from China, is causing serious political ripples. Opposition socialists, several prominent right wingers as the extreme right in France and political heavyweights in Germany have denounced the move to seek Chinese help.

Seeking help from China is being described as the attempt to ask China to back the Euro-zone's bail out fund as a 'Financial Munich' i.e. an appeasement of an ever voracious China. The Europeans began wooing the Chinese almost soon after the agreement in Brussels to boost the leveraged of the EFSF from the present Euro 4440 billion to nearly Euro 1.4 trillion. But China has made it increasingly plain that its nod to forking out some Euro 70 billion to back the EFSF. Chinese investments in the EFSF are of purely commercial nature, not linked to political concessions. 


\section{Significant View Point}

Global Billionaire Mr. Warren Buffet has right opined that Europe's debt crisis had shown a 'major flaw' in the 17 member euro-zone system and the same would take more than words to fix it. How Europe's sovereign debt crisis, which started in Greece two years ago and rages on, would end; there were good valuation among companies in Europe. Not in debt; space, but in the equity space there are opportunities as there are a dozen euro stocks that are of attractive nature and they may give good business.

\section{OECD's significant observations about crisis}

The Euro-zone stuck in mild recession. The threat of even more devastating downturns looms if the Euro zone does not get to grips with its debt crisis. In the absence of decisive strategy from Euro zone leaders, the European Central Bank (ECB) alone has the power to contain the bloc's crisis. Struggling to contain an unprecedented debt crisis, the Euro zone has already entered into a recession and would eke out growth of only 0.2 per cent in 2012 .

The OECD has opined that many questions about Euro zone's response to the debt crisis remain unresolved, raising doubts about even the bloc's most strong and sound economies as demonstrated by Germany's difficulties placing bonds with investors.

What the globe is seeing now is contagion rising and hitting probably Germany as well. Hence, the first thing, the absolute priority, is to stop that and in the immediate run the only actor that can do that is ECB. There is urgent need on the ECB to create a cap on Government bond yields as a way of calming the crisis.

\section{UK's Insistence}

Britain's insistence on having its say on the Euro zone has deepened UK's isolation in the European Union. This is a dangerous sign under the present trends and situation. This shows that the Europe is so much divided. A full blown war of words has come up between Britain and other European partners. Britain, that is not a member of the Euro zone and often gloats over its decision not to adopt the single currency, has been accused of meddling in the European affairs and sniping from the sidelines rather than helping in hard times to find the solution of the debt crisis. The existing division between UK and Europe has been proved by headlines of the News papers 'the sick Empire" and 'what is England still doing in the EU' at the eve of UK's Prime Minister visit to Germany.

The deep-seated euro-skepticism, bordering on visceral loathing among the ruling conservatives, UK has never been popular with its European counter parts. But in recent time, its isolation has further deepened and as a result what is widely perceived across the channel as its negative response to the crisis. The two top most authorities of UK's Government blame the developments in Euro zone for Britain own worsening economic difficulties.

Whereas it is widely acclaimed that the chaos in the Euro zone would inevitably have an effect on other European countries even if they are not part of the single currency. It is true that the UK's economic woes pre-dated the crisis in Euro zone. But UK's refusal to back or support Franco-German proposal for a Euro zone i.e. wide financial tax on grounds that it would hurt Britain business community interest is an indication of war between UK and EU partners. British are of the belief that the proposal of Franco and German would drive businesses away from UK

EU partners are of the view that the Britain is not a member of the Euro currency 
union but it is the member of European Union and hence, it is the responsibility of UK for bringing success to EU, and it must also share the cost of debt crisis. The Euro zone contagion spreads from Greece, Ireland, Portugal, Spain, and Italy and beyond, there is growing pressure on Germany to act by drawing on the resources of the ECB. This would mean that ECB would act as a Lender of Last Resort. This means the ECB should buy bonds of sick Euro zone countries which would result in higher inflation. Now there is no option on part of Germany to relent, the Euro zone could be headed for a crash, endangering the entire European Union.

\section{EU Agrees on New Treaty}

Europe stood divided in a historic rift over building a closer fiscal union to preserve the Euro, with a large majority of nations led by Germany and France agreeing to forge ahead with a separate treaty, leaving UK isolated. This is because 23 out of 27 members agreed upon pursuing tighter integration with strict budget rules and regulations for the single currency area. The most unfortunate issue is that UK did not accept proposed amendments to the EU treaty after failing to secure concessions for it.

All 17 nations of the Euro zone and 6 countries that aspire to join EU resolved to negotiate a new agreement alongside the EU treaty with a tougher deficit and debt regimes to insulate the Euro zone against the debt crisis. Sweden, Hungary, and the Czech Republic will ratify the new agreement from their respective parliaments.

There is a saying that not Europe, but Brits are divided and hence, Britain remained outside decision making. Europe is united. The Central Bank of Europe called the decision a step forward for the stricter budget rules and regulations that are essential if Euro zone is to emerge stronger from two years market turmoil.

This is to be a sound and strong basis for a good fiscal compact and more discipline in economic policy in the Euro zone members. The globe will see that Europe had learned from its mistakes and avoided lousy compromise. There is hope that Britain would eventually agree to change the EU treaty to anchor stricter budget discipline.

The leading role of ECB would be vital and strategic in the coming times with markets doubting the strength of Europe's financial firewalls to protect vulnerable economies such as Italy and Spain, which have to roll over hundreds of billions of Euros in debt next year.

The major player in European Union wanted to get the whole EU to agree to change the Lisbon Treaty so that stricter budget and debt rules and regulations for Euro zone countries could be enshrined in the bloc's basic law. UK did not fall in line with the European Union as it wanted guarantee in a protocol protecting its financial services which roughly made up one-tenth of the UK's economy.

May strained relations:

The new treaty of European Union may result into strained relations between the EU and UK. There is a possibility that London may try to prevent the other countries from using the executive European Commission and European Court of Justice. Clearly the "institutions of the European Union that belong to the European Union, also belong to 27 countries".

This is not a healthy trend and also not in the interest of entire Europe. The rift may rise and result into a pressure from Eurosceptics within Conservative party and outside it for Britain to hold a referendum on leaving the European Union, which it joined as back as 
in 1973. The British Prime Minister would strongly oppose such move and course, which he has said would be disastrous for UK's interests.

The big and stronger players in European Union are of the intention that there would be a forge in terms of intergovernmental treaty among Euro zone nations and others that wanted to join. These are of the view that the number of nations could be reduced to 25 in all with only Britain and perhaps Hungary may be left out.

\section{How US ratings giants affect the Euro-zone}

The crisis originated in the US is also responsible for the debt crisis in Europe. The credit rating agencies carry out creditworthiness of the bonds issued that resulted in lack of confidence and fear in the minds of the investors in the USA and the European Union. How it takes place can be seen from Figure 1.

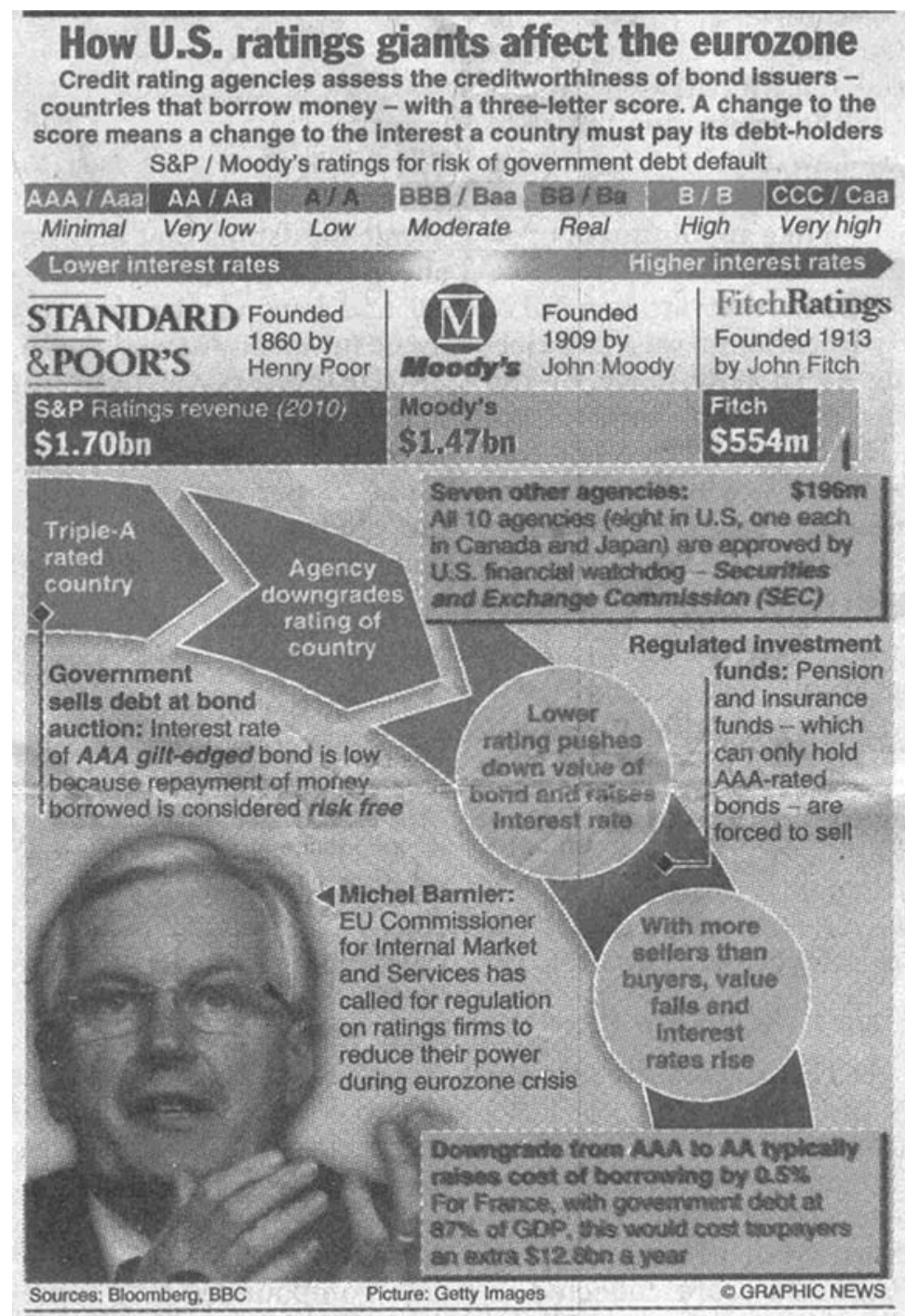




\section{Conclusion}

From the foregoing discussion it is evident that European Union is passing through a critical juncture and there is possibility that hard hitting economies of EU namely-Greece, Spain, Ireland, Italy and Portugal may opt out from the EU. External help from emerging economies is not certain. Hence, the future of European Union is in doldrums. The crisis would not be overcome by words. It needs concerted and serious efforts on the part of strong economies namely-Germany, France and Netherlands. By all accounts, it is the need of the hour for all Europeans to come together. But the isolation of UK may affect the exiting relations between EU and UK and there could be a cold war between them. In the long run, it is not in the interest of both EU and UK. The rift may have far reaching implications, consequences and impact on entire Europe in particular and the world in general.

\section{References}

Note of disappointment at Cannes; the Hindu; Chennai; November 6, 2011. P.9.

Suroor, H; Euro zone's Meddlesome Neighbors; the Hindu; Chennai; December 3, 2011; P.8.

Rioux, N; Investment Analyst; the Hindu; New Delhi; November 6, 2011; P. 9

Jobs crisis could spark unrest; the Hindu; New Delhi; November 2, 2011; P. 13

Gurria, A; Secretary General, Organization of Economic Cooperation and Development; OECD; Paris; 2011.

India warns against protectionism; the Hindu; Chennai; November 14, 2011; P. 10

Sharma, A; Union Minister of Commerce; Government of India; New Delhi; November 14; 2011.

G-20 urges Europe to act as Greece Teeters; the Times Business; New Delhi; November 5, 2011; P. 13.

Focus on structural reforms in G-20; the Hindu; Chennai; November 5, 2011; P. 5.

Gillard, G; Australian Prime Minister; Cannes; November 4, 2011.

Greece crisis shadow over G-20 Summit; the Hindu, International; New Delhi; November 4, 2011; P. 15.

Italy sells Euro 5 billion bills at highest rate in 14, years; the Time Business; New Delhi; November 11, 2011; P. 19.

Badiani, R; Economist; Global Insight; London; November 10, 2011.

France's top rating at risk; the Times Business; New Delhi; November 22, 2011; P. 13.

Knor, K; Governing Council Member, Dutch Central bank; Frankfurt; Germany; November $10,2011$.

Can't do more to stem crisis; the Times Business; New Delhi; November 11, 2011; P.20. 
China and Euro Crisis; the Hindu, International; Chennai; November 11, 2011. P.13.

Buffett, W; Words alone won't fix Euro zone crisis; the Times Business; New Delhi; November 22, 2011.

Global recovery petering out: OECD; the Times Business; New Delhi; November 29, 2011; P. 13.

Padoan, P.C; OECD Chief Economist; Paris; November 29, 2011.

Mr. Cameron, Prime Minister of UK and Chancellor George Osborne of Conservatives Party; UK; December 1, 2011.

EU agrees on new Treaty; the Times Business; New Delhi; December 10, 2011; P. 14.

Mrs. Angela Merkel; German Chancellor; Berlin, December 9, 2011.

Mr. David Cameron; the British Prime Minister; London; December 09, 2011.

Mrs. Angel Merkel; Chancellor of the Germany, Berlin; and Mr. Sarkozy; President of France; Paris. December 09, 2011.

It's the intangible that are the hardest things for a competitor to imitate. You can get an airplane. You can get ticket-counter space; you can get baggage conveyors. But it is our esprit de corps - the culture, the spirit - that is truly our most valuable competitive asset.

- Herb Kelleher, co-founder of Dallas-based Southwest Airlines, Time, 1999. 